\title{
HYPERTHYROIDISM IN ADOLESCENT WITH TYPE 1 DIABETES MELLITUS
}

\author{
M Luthfi Suhaimi' ${ }^{1}$ Eka Agustia Rini \\ ${ }^{1,2}$ Bagian Ilmu Kesehatan Anak, Fakultas Kedokteran Universitas Andalas/RSUP Dr. M. Djamil Padang \\ email: luthfi.suhaimi@yahoo.com
}

Submitted : 24-02-2020, Reviewer:26-02-2020, Accepted: 26-02-2020

\begin{abstract}
hyroid disorders and diabetes mellitus are the two most common endocrine cases in clinical practice. Autoimmune thyroid disease (AITD) being more prevalent in people with type 1 diabetes mellitus (TIDM), and the occurrence of both in the same patient is defined as autoimmune polyglandular syndrome type 3 variant (APS3v). We are presenting a 12-years-old girl with hyperthyroid and T1DM occured as diabetic ketoacidosis (DKA). Diagnosed by symptoms, physical examinations, and confirmed by laboratory results. Patient was treated with insulin injection and oral anti-thyroid drug, and had clinical improvement.
\end{abstract}

Keywords : Hyperthyroid, diabetes mellitus, diabetic ketoacidosis

\begin{abstract}
Abstrak
Gangguan tiroid dan diabetes mellitus merupakan dua kasus endokrin yang paling umum ditemukan dalam praktek klinis. Penyakit tiroid autoimun lebih sering ditemukan pada penderita diabetes mellitus tipe-1 (DM tipe-1), munculnya kedua kasus ini disebut sebagai sindrom poliglandular autoimun tipe-3. Laporan kasus seorang anak perempuan usia 12 tahun dengan hipertiroid dan DM tipe-1 dengan manifestasi awal berupa ketoasidosis diabetikum (KAD). Diagnosis ditegakkan berdasarkan gejala klinis, pemeriksaan fisik, dan hasil laboratorium. Pasien ini ditata laksana dengan injeksi insulin dan obat anti-tiroid oral dengan luaran perbaikan klinis.

Kata kunci : Hipertiroid, diabetes mellitus, ketoasidosis diabetikum
\end{abstract}

\section{INTRODUCTION}

Thyroid gland has a central role in the regulation of metabolism, abnormal thyroid function can make a major impact on the control of diabetes. ${ }^{1-3}$ Untreated thyroid disorders may increase the risk of DKA. ${ }^{4-6}$ Thyroid autoimmunity being more prevalent in people with type-1 diabetes mellitus (T1DM). The relationship between thyroid disorders and diabetes mellitus is characterized by a complex interaction.
Thyroid hormones contribute to the regulation of carbohydrate metabolism and pancreatic function, whereas diabetes affects thyroid function to variable extents. ${ }^{1,6-8}$

Hyperthyroidism is a condition of hyperfunction and overproduction of thyroid hormones. ${ }^{1,9}$ Diabetes mellitus describes a complex metabolic disorder characterized by chronic hyperglycemia resulting from defects in insulin secretion, insulin action, or both. Inadequate insulin secretion and/or diminished tissue responses to insulin in the 
complex pathways of hormone action result in deficient insulin action on target tissues, which leads to abnormalities of metabolism. ${ }^{10}$ It is essential to be suspected of the possibility of the coexistence of these two diseases, if DKA or hyperthyroid case is found. ${ }^{6}$ The occurrence of AITD in patients with T1DM is referred to as a variant of autoimmune polyglandular syndrome type 3 (APS3v). ${ }^{7}$

\section{CASE}

A 12-years-old girl with $7 \mathrm{~kg}$ weight loss, polyphagia, thirst, polydipsia, polyuria, and thyroid enlargement for 2 weeks before admission. She had complained palpitations, sweats, and emotional. No history of fever, breathlessness, vomitus, abdominal pain nor decrease of consciousness. No history of these complain previously, no history of diabetes and goiter in family.

Physical examination showed the patient was alert with normal vital signs, except tachycardia. Body weight was $25 \mathrm{~kg}$ (previous body weight was $32 \mathrm{~kg}$ ) and 146 $\mathrm{cm}$ in height. There was no anemia, edema, cyanosis, nor jaundice. No exophthalmus, pupil was isochoric with normal light reflex. A mild diffuse goiter was palpable, rubbery, flat surface, no bruit. There were no abnormality on his ear nor nose, oral candidiasis was found. Chest was symmetrical without retraction. Lung and heart were normal. Abdomen was normal, liver and spleen were not palpable. Puberty state was A1M1P1. Extremities were warm with good perfusion. Physiological reflexes were normal and no pathological reflexes.

Laboratory findings were hyperglycemia random blood glucose (RBG) $453 \mathrm{mg} / \mathrm{dl}$, glucosuria +3 , ketonuria +3, metabolic acidosis (blood pH 7.29, bicarbonate $8.9 \mathrm{mmol} / \mathrm{l})$. Hemoglobin $(\mathrm{Hb})$ $14.6 \mathrm{~g} / \mathrm{dl}$, leucocytes $5,630 / \mathrm{mm}^{3}$, thrombocytes $186,000 / \mathrm{mm}^{3}$, hematocrit $42 \%$, sodium $140 \mathrm{mmol} / \mathrm{l}$, potassium 3.4 $\mathrm{mmol} / \mathrm{l}$, calsium $8.5 \mathrm{mg} / \mathrm{dl}$. The glycosylated hemoglobin (HbA1c) level was 14\%, Cpeptide level was $0.4 \mathrm{ng} / \mathrm{ml}$ (normal range $(\mathrm{N})=0.9-7.1 \mathrm{ng} / \mathrm{ml})$, free thyroxine (FT4) level was $2.78 \mathrm{ng} / \mathrm{dl}(\mathrm{N}=0.81-1.66 \mathrm{ng} / \mathrm{dl})$, and thyroid-stimulating hormone (TSH) level was $<0.005 \mu \mathrm{IU} / \mathrm{ml}(\mathrm{N}=0.70-4.61$ $\mu \mathrm{IU} / \mathrm{ml})$.

This patient was diagnosed with diabetic ketoacidosis (DKA) due to T1DM, oral candidiasis, and hyperthyroidism. First management was to treat ketoacidosis condition. She got insulin infusion, continued by basal-bolus insulin, diabetic diet (divide into 3 meals and 3 snacks), oral anti-thyroid, and nystatin. In follow up (10 days hospitalization), there were clinical improvement. Patient and parents were educated regarding diagnosis, treatment, complications and prognosis. They were able to check capillary blood glucose, insulin injection, and tried to calculate calorie intake by themselves. She is treated with insulin basal-bolus regimens and oral anti-thyroid medication for discharge.

\section{DISCUSSION}

Type 1 diabetes mellitus (T1DM) is caused by the autoimmune destruction of pancreatic $\beta$-cells. T1DM is frequently associated with other organ-specific autoimmune disorders, such as autoimmune thyroid disease (AITD). AITD and T1DM frequently occur together in the same individual, defined as one of the variants of the autoimmune polyglandular syndrome type 3 (APS3v). ${ }^{7}$ The prevalence of thyroid disease in patients with T1DM varies in different population, generally influenced by genetic and environment factors. AITD including Graves disease and Hashimoto thyroiditis, are the most common organ-specific autoimmune disease which may occur as a complication in T1DM patients. Over $13-30 \%$ of patients with T1DM have thyroid dysfunction, ${ }^{4,} 16$ Graves disease prevalence in T1DM patients was 
$0.53 \% .^{3}$ Other studies found $0.46-7 \%$ for hyperthyroidism in T1DM patients. ${ }^{1,2,8,16}$

A case described a patient who developed new onset of T1DM, presented with diabetic ketoacidosis, and hyperthyroid. The diagnosis was made based on symptoms, physical examinations, and confirmed by laboratory results. Classic symptoms of diabetes mellitus are polydipsia, polyuria, and polyphagia; with plasma glucose concentration $\geq 200 \mathrm{mg} / \mathrm{dl}$ or HbA1c $>6.5 \% .{ }^{10}$ We found that the patient had classic triad of DM symptoms such as polyphagia, polydipsia, polyuria, with hyperglycemia (plasma glucose was 453 $\mathrm{mg} / \mathrm{dl})$. Physical examination showed there were no decrease of consciousness nor shock, normal blood pressure and good perfusion, no tachycardia nor tachypnea.

DKA is a diabetic emergencies, occurs as a result of elevated glucagon levels and absolute insulin deficiency. Failure to consider the possibility of diabetes may result in late diagnosis and may increase risk of DKA, approx 35-40\% lead to diabetes ketoacidosis. ${ }^{11}$ The biochemical criteria for the diagnosis of DKA are hyperglycemia, low blood $\mathrm{pH}$ and bicarbonate, ketonemia and ketonuria. The severity of DKA is categorized by the degree of acidosis, described as mild if venous $\mathrm{pH}<7.3$ or bicarbonate $<15 \mathrm{mmol} / \mathrm{l}$, moderate if $\mathrm{pH}<7.2$ or bicarbonate $<10$ $\mathrm{mmol} / \mathrm{l}$, and severe DKA if $\mathrm{pH}<7.1$ or bicarbonate $<5 \mathrm{mmol} / \mathrm{l} .{ }^{12}$ In this case, blood gas analysis indicated metabolic acidosis (blood pH 7.29 and bicarbonate $8.9 \mathrm{mmol} / \mathrm{l}$ ), glucosuria +3 and urinary ketone bodies was +3 , suitable for mild DKA.

Impaired insulin secretion and/or action may coexist in the same patient. Its important to differentiate between type-1 or type- 2 diabetes at diagnosis. This case had rapid onset, suitable with T1DM. T1DM ussualy primarily lean. ${ }^{11}$ Patient nutritional status was undernourish, body weight (BW) was $25 \mathrm{~kg}$ (decreased $7 \mathrm{~kg}$ over 2-weeks period), ideal BW is $40 \mathrm{~kg}$. Heigth was 146 $\mathrm{cm}$, height-age suitable with 11-years-old girl. On further laboratory check, the Cpeptide level was low $(0.4 \mathrm{ng} / \mathrm{ml})$, and HbA1c level was high (14\%), which indicated T1DM, and poor glycemic control condition.

The HbA1c is an excellent indicator to monitor glycemic control. A single blood glucose test can only tell us how the blood glucose control was at a certain point in time, but the HbA1c level reflects the average blood glucose level during the life of the red blood cell (approx 100 days). Good diabetes control will result in an HbA1c level of $<6.5 \% .{ }^{13} \mathrm{C}$-peptide is a byproduct of insulin made in the pancreas. The level of C-peptide in the blood can indicate whether or not a person is producing insulin and roughly how much. ${ }^{11,13}$

T1DM has comorbid conditions with other autoimmune disorders such as thyroid disease. In this patient, thyroid gland was enlarged, but no exophthalmus found. Chest and abdomen condition was in normal limit. The symptoms of hyperthyroidism such as unexplained weight loss without loss of appetite was signs of T1DM and hyperthyroid. Heat intolerance and sweating, fatigue and weakness, and also the thyroid gland enlargement were the typical clinical features of thyroid disorders. ${ }^{14}$

Thyroid function tests should be performed soon after a period of metabolic stability and good glycemic control. Abnormal thyroid function can easily be diagnosed by simple blood tests, and effective treatment is available. The diagnosis of hyperthyroidism begins with an accurate clinical history and physical examination, confirmed by TSH and FT4 laboratory tests. TSH test is the best firstline test to evaluate thyroid function. TSH 
levels below the normal range and elevated FT4 suggest a possible hyperthyroidism, if the TSH is suppressed but FT4 level is normal, the hyperthyroidism is subclinical. ${ }^{14}$ Laboratory tests showed that FT4 was high $(2.78 \mathrm{ng} / \mathrm{dl})$ and TSH level was low $(<0.005$ $\mu \mathrm{IU} / \mathrm{ml}$ ) with impression hyperthyroid.

Hyperthyroidism is treated with antithyroid drugs such as carbimazole or propylthiouracil are required to achieve euthyroidism; carbimazole is the preferred treatment in children due to the increased risk of liver failure in patients treated with propylthiouracil. This patient has received carbimazole. Thyroidectomy and radioiodine are less used, particularly in people with very large goiters. ${ }^{15}$

Insulin treatment must be started as soon as possible after diagnosis to prevent metabolic decompensation. ${ }^{14,} 16$ In acute phase, this patient was treated with insulin infusion therapy for correction of hyperglycemia, then there were no complaint and physical examinations were in normal limit, urinary ketone bodies was negative and RBG level was within normal range. Accordingly, diabetic diet was initiated to give diabetic diet, divided into 3 meals and 3 snacks, and insulin basal-bolus regimens.

Daily insulin dosage varies greatly and changes over time. Therefore, it requires regular review and reassessment. ${ }^{16}$ We use premeal bolus injections together with a basal (long-acting) analog given twice daily. ${ }^{17}$ At first, insulin dose was devided into basal insulin $50 \%$ and bolus insulin $50 \%$ of the total daily insulin requirements, with regular review and reassessment according to blood glucose level. The patient was discharged at $10^{\text {th }}$ day hospitalization, with serial BG range 86-128 $\mathrm{mg} / \mathrm{dl}$, total insulin dose was $1.4 \mathrm{IU} / \mathrm{kg} / \mathrm{d}$ (range 1.2-1.6 IU/kg/d), and BW increased to $27 \mathrm{~kg}$.
Intensive education and some practical skills are the key to successful management and prevent complications of diabetes. ${ }^{18}$ This patient is the first child, her parents are a junior high school graduated farm worker, and both parents have the ability to examine blood glucose, insulin injection and insulin dose adjustment by them selves and carb counting.

Clinically evident diabetes-related vascular complications are rare in childhood and adolescence. However, early functional and structural abnormalities may be present a few years after the onset of the disease. Improvement in glycemic control will reduce the risk of onset and progression of diabetes vascular and metabolic complications. ${ }^{19,20}$

\section{REFERENCES}

1. Orzan A, Carmen N, Mihaiela M, Constantin I, Mihaela B. Type 1 diabetes and thyroid autoimmunity in children. J Clin Med. 2016;11:308-12.

2. Dost A, Rohrer TR, Fröhlich-Reiterer E, Bollow E, Karges B, Böckmann A, et al. Hyperthyroidism in 276 children and adolescents with type 1 diabetes from Germany and Austria. Horm Res Paediatr. 2015;84:190-8.

3. Lombardo F, Messina M, Salzano G, Rabbone I, Lo Presti D, Calcaterra V, et al. Prevalence, presentation and clinical evolution of Graves' disease in children and adolescents with type 1 diabetes mellitus. Horm Res Paediatr. 2011;76:221-5.

4. Mercer V, Burt V, Dhatariya KK. New onset type 1 diabetes presenting as ketoacidosis simultaneously presenting with autoimmune hyperthyroidism-a case report. J Diabetes Complications. 2011;25:208-10. 
5. Hage M, Zantout MS, Azar ST. Thyroid disorders and diabetes mellitus. J Thyroid Res. 2011;1-7.

6. Kobashi C, Muranaka E, Motoyoshi K, Satou Y, Ikeda T, Shigeta K, et al. Diabetic ketoacidosis due to simultaneous acute-onset type 1 diabetes and graves' disease. J Diabetes Metab. 2016;7:2155-6.

7. Horie I, Kawasaki E, Ando T. Clinical and genetic characteristics of autoimmune polyglandular syndrome type 3 variant in the Japanese population. J Clin Endocrinol Metab. 2012;97:1043-50.

8. Zamanfar D, Aarabi M, Sadeghian I. Type 1 diabetes mellitus associated with autoimmune thyroid disorders in Iranian children: a review. J Pediatr Rev. 2015;3:1-5.

9. Srinivasan S, Misra M. Hyperthyroidism in children. Pediatr in Rev. 2015;36:239-48.

10. Craig ME, Jefferies C, Dabelea D, Balde N, Seth A, Donaghue KC. Definition, epidemiology, and classification of diabetes in children and adolescents. Pediatr Diabetes. 2014;15:4-17.

11. Couper JJ, Haller MJ, Ziegler A-G, Knip M, Ludvigsson J, Craig ME. Phases of type 1 diabetes in children and adolescents. Pediatr Diabetes. 2014; 15:18-25.

12. Wolfsdorf JI, Allgrove J, Craig ME, Edge J, Glaser N, Jain V, et al. A consensus statement from the international society for pediatric and adolescent diabetes: diabetic ketoacidosis and hyperglycemic hyperosmolar state. Pediatr Diabetes. 2014;15:154-79.

13. Rewers MJ, Pillay K, de Beaufort C, Craig ME, Hanas R, Acerini CL, et al. Assessment and monitoring of glycemic control in children and adolescents with diabetes. Pediatr Diabetes. 2014;15:102-14.

14. Hanley P, Lord K, Bauer AJ. Thyroid disorders in children and adolescents: a review. JAMA Pediatr. 2016;170:100819.

15. Ross DS, Burch HB, Cooper DS, Greenlee MC, Laurberg P, Maia AL, et al. 2016 American thyroid association guidelines for diagnosis and management of hyperthyroidism and other causes of thyrotoxicosis. 2016;26:1343-98.

16. Ardestani SK, Keshteli AH, Khalili N, Hashemipour M, Barekatain R. Thyroid disorders in children and adolescents with type 1 diabetes mellitus in Isfahan, Iran. Iran J Pediatr. 2011;21:502-8.

17. Danne T, Bangstad H-J, Deeb L, JaroszChobot P, Mungaie L, Saboo B, et al. Insulin treatment in children and adolescents with diabetes. Pediatr Diabetes. 2014;15:115-34.

18. Lange K, Swift P, Pankowska E, Danne $T$. Diabetes education in children and adolescents. Pediatr Diabetes. 2014;15:77-85.

19. Donaghue KC, Wadwa RP, Dimeglio LA, Wong TY, Chiarelli F, Marcovecchio ML, et al. Microvascular and macrovascular complications in children and adolescents. Pediatr Diabetes. 2014;15:257-69.

20. Kordonouri O, Klingensmith G, Knip M, Holl RW, Menon PSN, Aanstoot HJ, et al. Other complications and diabetesassociated conditions in children and adolescents. Pediatr Diabetes. 2014;15:270-8. 